Book Review

\title{
Elementary Schools of Art in Hungary are the Key to Increasing One's Chances, Disadvantage Compensation and Multilateral Self-Development
}

\author{
Kiss Julianna ${ }^{1}$ \\ Recommended citation: \\ Kiss, J. (2021). Elementary Schools of Art in Hungary are the Key to Increasing One's Chances, Disadvantage \\ Compensation and Multilateral Self-Development. [Review of the book The elementary school of art as a school type to \\ increase one's chances, by Szücs, T.] Central European Journal of Educational Research, 3(1), 131-133. https://doi.org/ \\ 10.37441/CEJER/2021/3/1/9361
}

Bibliography of the reviewed book: Szűcs, T. (2019). Az alapfokú művészeti iskola, egy esélynövelő iskolatípus. Debrecen: Debreceni Egyetemi Kiadó. 190., 978-963-318-768-5.

\section{Introduction}

The dynamically expanding segment of researches in pedagogy studies the relations between education, cultural consumption and transfer. The book series "Education research in the 21 century" published by the University of Debrecen depicts the relations between public education processes that are growing and becoming more complex. A publication presenting research results in music appears for the third time on the pages of the series showing new results in the sphere of education research. Szücs Tímea's monograph "The elementary school of art as a school type to increase one's chances" is the ninth part of the series.

\section{Review}

The volume starts with defining the basic notions of the research - elementary school of art, recruitment, cultural capital, social capital, disadvantage, dropout, and biography of music education - thus the reader gets a clear view of the author's interpretation of specialized literature. Among the analysed notions of special interest is the term "biography of music education" that was introduced by the author and refers to music learning activity both on the part of the parents and the children based on eight components. The parents' music learning career, their own experience (institutional music education and the current activity related to music) play an important role in the formation of the family's cultural capital that is one of the central domains of the present research.

The guiding principle of the specialized literature overview that takes up two chapters of the volume is the educational policy, historical, and educational sociology approach. The starting point of the theoretical part is the chronological introduction of Hungary's musical education institutional system, its history and changes from the beginning up to the 21 st century. The knowledge of the relevant educational sphere's history and changes in legislation is indispensable to understand educational policy decisions, although they are sometimes too rich and condensed. The reader's attention is kept by smooth, highly readable wording, as well as logical progression from the general to the specific. After introducing the development of music lesson and instrumental teaching of music, the reader's attention is directed towards elementary schools of art. Having determined the place of musical training, the book describes how elementary schools of art function in Hungary, their spread and rate in various regions, thus offering valuable and relevant conclusions on the theme for further researches. The chapter touches upon the forms of learning applied in musical education as well. The peculiarity of this chapter is the "hidden curriculum" and the interpretation of leadership from the managerial point of view in the context of learning music and organization of the teaching process. This chapter introduces the author's suppletory work and we get a subtle insight into the elementary teaching of music from the historical, territorial, and sociological points of view.

1 Ferenc Rákóczi II. Transcarpathian Hungarian Institute (Ukraine); University of Debrecen (Hungary); cskissjulianna@gmail.com 
The author quotes the well-known 20th century teacher of music Jacques Dalcroze - musical experience counterbalances the modern troubled lifestyle. The book's third chapter analyses the social significance of learning music according to five points of view describing in detail the influence of music on health, physical development, emotional intelligence, and self-development, thus summarizing the results of long-established musical skill transfer influence, elucidating the disadvantage compensating and community building roles of music. The chapter's significance lies in the fact that the theory on capital, once related to the economy, then in the 19th century taking root in social sciences, is analysed in its relation to teaching of music. The author reveals that students' extracurricular activities can be effective investments both into cultural and social capital.

By analysing Bourdieu's, Coleman's, Putnam's, Granovetter's and Bandura's interpretations of capital the author draws us to the conclusion that the study of music and other branches of art, as well as the points of connection of cultural capital should be sought in increased education via theoretical studies, academic programs, in the time spent to learn music, in the orderliness necessary to master music, as well as in consistency. A significant part is devoted to elementary art training and social capital as it was expected in depicting the role of music in community building and disadvantage compensation. These types of institutions have a strong sense of belonging to a team (students with similar interests, opportunities to play music and sing together). The relations cultivated at school can remain even after finishing school, thus significantly contributing to increasing the child's social capital. Relations network and the increase of social capital are beneficial for academic efficiency. The author elucidates the connection between learning music and social capital beyond the community building influence and networking in an area that is more subjective and is closer to emotional intelligence. Trust between the teacher and the student is manifested not only in the course of teaching music but also in the collective playing of music that reaches completely new depth during concerts that follow lessons and rehearsals for the success of a performance can only be the result of a joint effort, synchronized, predictable and reliable work.

The volume's fourth and fifth chapters analyse the notion of cultural learning, then introduce the research "Music learning in Hungary in 2017" supplementing it with its antecedents and background information. The research has been conducted by means of the quantitative method. It attempts to and does map those special peculiarities that distinguish students learning music from their peers in the three county seats under analysis. The study conducts a comprehensive theoretical analysis of emerging cultural, economic and social capital, as well as academic efficiency and the motives behind learning music based on a 551-person sample. Presenting research results is not limited to these themes. The author enriches them with historical relations and depicts the economic status, characteristic features of the population of the geographical area under analysis. As a result, the relation between the social and cultural capital, as well as learning music acquire a much more profound interpretation. The research is topical for elementary art education has undergone significant transformations in recent years; music- and art education have become part of public education. The increasing variety of schools caused changes in recruitment and the role played in the musical art institution.

The book tries to answer two important questions: whether teaching of music that formerly belonged to elite education has become open to other social layers as well, thus compensating for their social and economic disadvantage; if teaching of music can adjust social disadvantages manifested in better academic results, higher academic motivation, the choice of higher-level school types; whether art education, realized by elementary schools of art exerts its influence on the territorial level as well; if it can perform the disadvantage compensating function for settlements and areas with social and economic indices that are below the average national level.

The book reveals for the reader whether students of music possess a higher cultural capital. Families with a musical biography regard various extracurricular activities as a kind of investment for they contribute to achieving a higher status in the social hierarchy or keeping the current one. Although the research results focus on learners, other actors of education, especially the parents, institution administration and pedagogues will also find conclusions that can be applied in practice. Due to the peculiar character of financing institutions teaching art and music, the number of students is a highly influential factor. A highly topical question every year is how to make teaching of music attractive, as well as how to reduce the varying dropout number of students. The book answers these questions by offering valuable data and conclusions, by analysing the motivation of children learning music both before "schooling" and in the course of their studies. Taking these motivations into account in the functioning of elementary schools of art and music can increase the efficiency of musical education, make their actors more satisfied, give a real sense of achievement, improve one's view of the institution, and contribute to the positive (transfer) influence of learning music.

The book is significant and modern in many aspects. There are numerous researches of higher and public education institutions, however the recruitment of elementary schools of art has not been studied yet. The 
presented research provides a comprehensive analysis of the social and cultural background of students studying music. The monograph studies the transformation process of music instruction system of institutions in historical, territorial and social aspects with special attention to the period between 1993 and 2016. Research results ought to be emphasized, just like categorizations bearing additional information and based on wellgrounded research decision: the families' objective financial situation clusters, groups formed on the basis of cultural consumption traditions, as well as family environment clusters based on capital types.

Examining the book cover we do not feel that it is for the academic audience only. This volume is highly topical for the academic community. It offers insight into the music learners' social and economic background, their problems, difficulties, and explains how to decrease dropout. However, it would be a good read for heads of institutions, teachers of music, parents, university and institute students, as well as the non-professional interested in the field.

Funding: This research received no external funding.

Acknowledgments: No additional acknowledgements.

Conflicts of Interest: The authors declare no conflict of interest.

(C) 2021 by the authors. Submitted for possible open access publication under the terms and conditions of the Creative Commons Attribution (CC BY) license (http://creativecommons.org/licenses/by/4.0/). 